\title{
Pre-Service Teachers' Approaches to the Effectiveness of Micro-Teaching in Teaching Practice Programs*
}

\author{
Samson Kifletsion Elias ${ }^{1,2}$ \\ ${ }^{1}$ College of Education, Eritrea Institute of Technology, Himbrti, Eritrea \\ ${ }^{2}$ Central China Normal University, Wuhan, China \\ Email: samik747@yahoo.ca
}

How to cite this paper: Elias, S.K. (2018) Pre-Service Teachers' Approaches to the Effectiveness of Micro-Teaching in Teaching Practice Programs. Open Journal of Social Sciences, 6, 205-224.

https://doi.org/10.4236/jss.2018.65016

Received: April 14, 2018

Accepted: May 26, 2018

Published: May 29, 2018

Copyright $\odot 2018$ by author and Scientific Research Publishing Inc. This work is licensed under the Creative Commons Attribution-NonCommercial International License (CC BY-NC 4.0).

http://creativecommons.org/licenses/by-nc/4.0/

\begin{abstract}
This study focuses and critically analyzes the contribution of micro-teaching on teacher attitude according to pre-service teachers' opinions based on their teaching practice program. The program was implemented at the College of Education in Eritrea Institute of Technology to prepare pre-service teachers. This research investigates that if there are any differences about pre-service teachers' views after engagement of micro-teaching practices. The participants of the study are undergraduate diploma students who are in the department of teacher education ${ }^{1}$ in a diploma program in the 2015-2016 academic years. Students made a presentation practicing micro-teaching methods at the middle school curriculum of the Eritrean context. At the end of the training, semi-structured interview was used to assess their views about General Methods of Teaching (GMT) in the classroom. The result of the interview shows that pre-service teachers believed that the micro-teaching method gives a chance to evaluate their strength and weakness in the aspects of teaching. Apparently, the interview result exhibited that pre-service teachers were able to establish skills of: planning, questioning, assessment, management of student's misbehavior, applications of teaching materials, and positive attitude towards the profession during the teaching process. The report calls on teacher educators in a different context to work together on similar initiatives that help pre-service teachers grow professionally through designing, developing and promoting their experiential learning projects to enhance human development and improve conditions.
\end{abstract}

\section{Keywords}

Micro-Teaching, Pre-Service Teachers, Teaching Practice, Teacher Education

*This study supported by the offering department of curriculum instruction of the College of Education in Eritrea Institute of technology (E.I.T) with research team project collaboration. ${ }^{1}$ Science Education, Social Education, and ELT. 


\section{Introduction}

The reason some societies are more advanced than others and all the development witnessed in this increasingly competitive world today can be explained as being the result of the education system (Psacharopoulos \& Patrinos, 2004). The highest level of our civilization, development, or technological advancement we have achieved as humans is the result of all the education, philosophy, and ideas in different fields and areas of our lives (Indicators, 2012). That is why developed countries give great support to education, as the future is only possible for them to have power and voice by educating people who are experts in their own fields (Kember \& Leung, 2005) [1].

Different factors have an effect on the education of qualified people. And without doubt, one of the most important factors is the teacher. The teacher has the key role in learning and teaching process. The most important role of the teacher in school is to guide students while providing knowledge. With this role, the teacher shapes the terminal behaviors of the students, helps the student to have a positive relationship and make them skillful (Gess-Newsome, 2015) [2]. Moreover, the teacher has to be and is expected to be a role model in teaching with the feeling of worthiness. Teachers need to have tolerance in order to develop the individual entrepreneurship and creativeness (Crosby, 2000) [3]. However, "Teacher education" is a multidimensional and universal issue, and each component of it is tied and appreciated. The concept of training teachers includes sub-subjects such as the selection of the teacher candidates, their prevocational training. In another word, the development of any nation largely depends on the effectiveness of teaching process it possesses while in the heart of it lies the teacher (Avalos, 2011) [4].

Teachers need not only to be equipped with sound pedagogies and solid professional knowledge but also to acquire competence in dealing with shifting contextual conditions, which adds complexities of educational practices [5] [6]. This requires pre-service teacher education programmes to prepare teachers with sufficient experience of engaging with significant social and cultural issues that profoundly mediate educational practices in particular context and beyond. Therefore, microteaching as one component plays significant effort to make teacher education program scientific, productive and meaningful. It was developed by Professor Dwight Allen and Robert Bush, in teacher preparation program at Stanford University between 1960 and 1967. It is now considered as one of the most critical developments in the field of teaching practice in many countries. "Micro-teaching" is not only a constructive teacher training technique but also "a versatile research tool which dramatically simplifies the logistics of inves- 
tigating certain teaching skills and learning variables" [7]. In Eritrea, the faculty of Education revised its Teaching practice 2014 and introduced this method for its student teachers ${ }^{2}$ which involved a more comprehensive approach to learning how to become a teacher. This method will continue in 2018 with minor changes.

\section{Micro-Teaching Procedure in Education}

Micro-teaching is like a stimulated social skill teaching to provide the feedback to teacher trainee for the modification of teacher behavior. It is training concept that applies at various pre-service and in-service stage in the professional development of teachers. It provides teachers with a practice setting or instruction in which the normal complexities of the classroom are reduced, and the teacher gets feedback on his performance [8]. This initiative at the college draws on dialectical relationship between knowing and doing advance by Wang Yang Ming who argued "knowing and doing are unified" and American scholars including John Dewey and Jean Lave, who conceptualized learning as a social process of knowledge construction in particular context [9]. The experiential learning initiative aims to nurture pre-service teachers in to critically mind reflective professionals capable of teaching in local and international educational contexts. It refers to a variety of teaching of credit-bearing and non-credit-bearing learning opportunities that enable pre-service teachers to take up an active, analytical and reflective role.

Microteaching has been defined differently by the experts. According to Allen [10], it is a "scaled down teaching encounter in class size and time" [11]. As Clift, Batten [12] have defined microteaching as a teacher training technique which diminishes the teaching condition to simpler and more skillful encounter achieved by regulating the practice teaching to a specific skill and dropping teaching time and class size.

Microteaching is a method that has been used since the 1960 s in teaching-learning environments; it is a remarkable factor used in teaching practices of pre-service teachers [13]. Also, microteaching method offers new and different opportunities to pre-service teachers about the planning and implementation of new teaching strategies [14]. However, Microteaching has an essential place in groundwork for the teaching profession because of its perspective to underline the relationship between theory and practice [15]. Microteaching is a technique in teacher education provides a transition from theory to real teaching situation [16].

According to Kochhar [17], Micro-teaching has the following significant characteristics:

1) Microelement: reduces the complexities of teaching regarding, a) number of students to be taught, b) duration of lesson, c) subject-matter to be taught to enable the trainee to concentrate on particular teaching skill at a time.

2) Teaching skill and teaching strategies: a) pre-instructional skill, b) instructional skills

'In this paper "student teachers" refers to college students, while "student" refers to the middle school learners in Eritrean schools. 
3) Post instructional skills

a) Feedback: in microteaching several reliable and authentic source employed for providing necessary feedback. Some of them are like oral feedback by the supervisor, observation schedules filled in by the supervisor, observation schedules filled in by the peer group participating in the micro lesson, audio, and videotape recording.

b) Safe practice ground: A micro-teaching laboratory possesses all the inherent features of the real classroom. Teaching performed under simulated conditions with a small group; the trainee is on a safe practice ground.

c) The teaching models: the trainee gets many opportunities to study the desired pattern of behavior through demonstration given by the supervisor, or a tape or a film. With the help of these models as a guide, the trainee can develop his style.

According to Allen and Eve [18], micro-teaching is a system of controlled practice that makes it possible to focus on a specific teaching behavior and to practice teaching under controlled condition. Moreover, thus, pre-service try to bridge the gap between the theory and practice [19].

In microteaching practice, lesson duration is short (5 - 20 minutes), and the number of students is few (not more than 20) in a group of 4 students at least [20]. In respect to the subject, teachers work to meet only one teaching skill. Microteaching is a series cycle which started with planning. As shown in Figure 1, micro teaching cycle is a process of teaching, criticism, re-planning, re-teaching and re-criticizing [21].

In this process of the cycle, pre-service teachers prepared the lesson plan that the subject is determined before. In teaching stage of the cycle, the pre-service teachers perform micro lesson to real students that were planned and prepared by them each group their lesson collaboratively. Also, lectures recorded by a video camera or portable receiver. Then pre-service teachers made to watch and hear themselves from the recording at the end of the lecture. In critique stage, pre-service teachers' micro lesson reviewed, discussed, analyzed and evaluated.

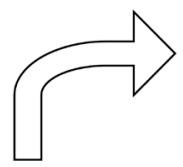

RE-CRITICIZING

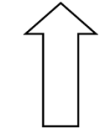

RE-TEACHING

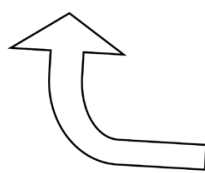

PLANNING

RE-PLANNING

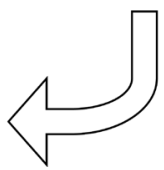

Figure 1. Stages of microteaching. 
Pre-service teachers prepared the lesson plan again and a re-teach micro lesson to the same group. Also, the second micro lessons recorded by a video camera or portable receivers. After watching the second micro lesson from recording, the teacher and peers present their critiques which were about the worst or better sides between first and second micro lessons.

\section{Objectives of the Research}

- To make the teacher education program scientific, productive, and meaningful in the Eritrean educational context.

- To promote the quality of students by creating opportunities to transfer their teaching knowledge into practice.

- To prepare pre-service teachers with less anxiety and easiness.

- To have consistency among supervisors with their respective trainees on assessments and evaluations.

- To enable the pre-service teachers to gain confidence in teaching, mastering some teaching skills on small group students, and assimilated skills under controlled conditions.

- To utilize the academic potential of teacher-trainees for providing much-needed feedback.

- To examine microteaching practice on the contribution of teacher qualifications according to pre-service teachers' which based on their teaching experiences.

\section{Methodology}

The study consists of qualitative data. The data cover interviews with student teachers from a randomly selected number of students and some supervisors. In addition to its focusing on their narratives, the data enabled me to get an insight into what role microteaching in teaching practice is playing in student's everyday life of teaching and learning. How much time is spent on collaboration works, how experiences from teaching the practice of the college to influence their feeling and mood in teaching, and learning as well as what are the learning and studying conditions of the college student teachers.

Although qualitative research aims to compare the views of the prospective students before and after micro-teaching application which makes it comparative research, it is also the explanatory type of research for its engagement of its new experience to the teacher education college of the Eritrean context.

\subsection{The Research Instrument}

The tool used to gather data in this study was, semi-structured interview form and micro-teaching performance checklist prepared by the teacher education department of curriculum and instruction. At the end of the microteaching phase, eight questions asked to pre-service teachers, One and general question to advisors of academic staff to evaluate microteaching about the general method of teaching training. Microteaching period applied as part of teacher training les- 
son. After that eight different questions about teaching program were asked to the participants so that they could evaluate the microteaching application so that they could evaluate the microteaching application they already had at the same time the performance checklist was filled pre and post presentation of the pre-service teachers by supervisor. The investigation also was done by taking notes during each interview. The interview questions are listed below in Table 1.

\subsection{Participants}

Participants in this research were 15 students of the diploma programs ${ }^{3}$ in the college of education in Mai-nefhi Eritrean Institute of Technology (E.I.T). Moreover, easily accessible sample technique was used. This technique increases the speed and accuracy. The data were obtained from those pre-service teachers and three supervisors who were willing to participate in the research after being exposed to the microteaching application by the coordinators of the teaching practice.

\subsection{The Data Analysis}

Data obtained with the support of an interview with the participants for a comparative analysis of pre and post presentations evaluation checklist. After that, it was transferred to a computer for an Excel to form the digital data. In the form of Barograph, finally, content analysis was made with the percentage and frequency values.

\section{Limitations}

This study dealt only with Diploma program for pre-service teachers, but future

Table 1. Interview questions.

\begin{tabular}{|c|c|c|}
\hline Q.N & $\begin{array}{l}\text { Semi-structured } \\
\text { Interview }\end{array}$ & Questions \\
\hline Q1 & & $\begin{array}{l}\text { You have difficulties in teaching before you start to teach in } \\
\text { microteaching? }\end{array}$ \\
\hline Q2 & Do you think & $\begin{array}{l}\text { That watching or observing the presentations/videos of microteaching } \\
\text { practice with your friends provides any benefits to you? }\end{array}$ \\
\hline Q3 & & There is any difference between your first and second presentation? \\
\hline Q4 & & $\begin{array}{l}\text { Watching the presentation videos with using the microteaching } \\
\text { technique of your friend contributes? What? }\end{array}$ \\
\hline Q5 & $\begin{array}{l}\text { What do you } \\
\text { think about the }\end{array}$ & The use of microteaching method in the teaching practice lesson? \\
\hline Q6 & $\begin{array}{l}\text { What are some } \\
\text { limitations of }\end{array}$ & Applications of microteaching techniques of teaching practice? \\
\hline Q7 & & The application of microteaching for better improvement? \\
\hline Q8 & $\begin{array}{l}\text { What is your } \\
\text { suggestion for }\end{array}$ & $\begin{array}{l}\text { The advisor of academic staff about the implementation of the } \\
\text { microteaching methods? }\end{array}$ \\
\hline
\end{tabular}

${ }_{3}^{3}$ Departments of Science Education, Social Science Education, Mathematics Education and English Language Teaching. 
studies that include Degree program student teachers contestants may generate data that are more diverse. The pre-service teacher's replies to some of the items might have been affected by assuming that their microteaching grade could be partially based on the kind of response they provided. Further, a limitation that may hinder the success of this method is all the participants trying to apply it to the whole coverage of the course GMT. However, GMT gives high emphasis to teaching skills and techniques. Moreover, another very important limitation that demands a great concern of the organizing committee are regarding program timing, and per-diem was not as motivational as was supposed to be for supervisors. Despite the limitation above, this study made crucial contributions to better understand and improve certain aspects of teacher education program in situations where the microteaching application is considered as new.

\section{Research Findings and Presentations}

\section{Background}

This section presents some key information about the student teachers' academic performance, cultural, social and economic background. Knowing the background of the pre-service students will provide information about the background on which they perceive the microteaching method as well as teaching profession and assess the teacher education in general. It is well known and recognized the fact that the school and education in Eritrea are weak regarding providing education for girls/women and regarding equal representation of nine ethnic groups. However, there is a clear policy from the government to work on educational innovation and change that will increase the enrolment of girls and the ethnic groups [22].

As shown in Graph 1 and Graph 2, the number of male student teachers in the whole teaching practice program is more than three times as high as the number of females in the program and assigned among 30 supervising staff. The majority of the female students join Science Education and English language teaching (ELT) departments.

Majority of the student teachers join from the department of science education in both degree and diploma programs. This is not surprising in Eritrean context, and the majority of them from the Biology department, very few from physics join the teaching practice program each year (Graphs 3-5).

The academic performance of the pre-service teachers based on their status ${ }^{4}$ of the semester before joining this program was not satisfactory, because many of them were on Probation status as well as some readmitted transferred student teachers (Graph 6).

\section{Results}

The findings resulting from the responses given by the pre-service teachers and

${ }^{4}$ Probation status is when their semester GPA $(\mathrm{X}), 1.75<\mathrm{X} \leq 2.00$, Good standing status is when both their semester GPA (X) and CGPA (Y), Y $\geq 2.00 \leq \mathrm{X}$, Transferred student teachers were those Degree Dismissed for Good. 


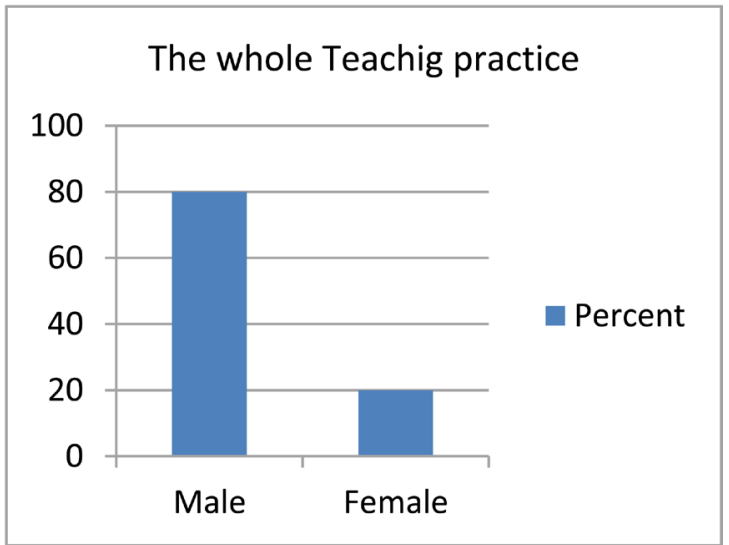

Graph 1. Gender of population.

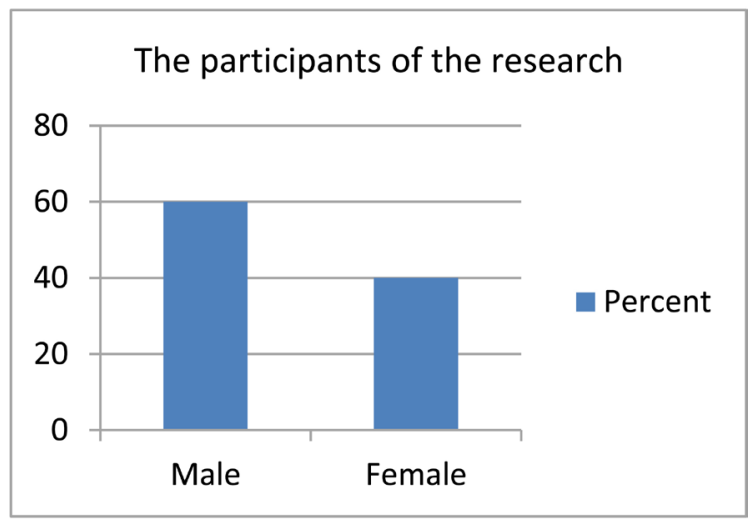

Graph 2. Gender of the sample.

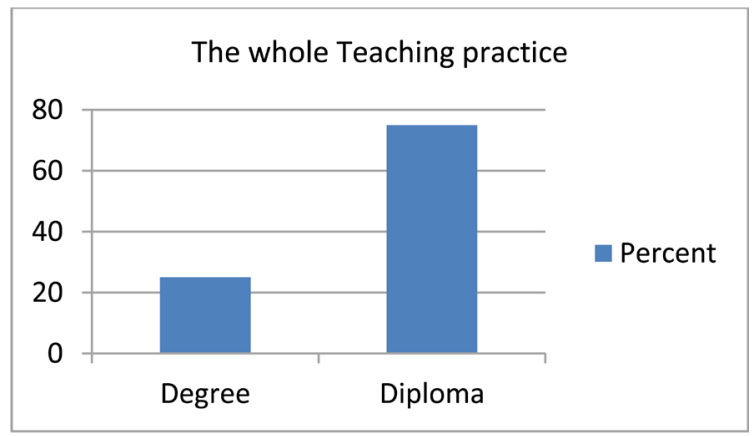

Graph 3. Participants of the program.

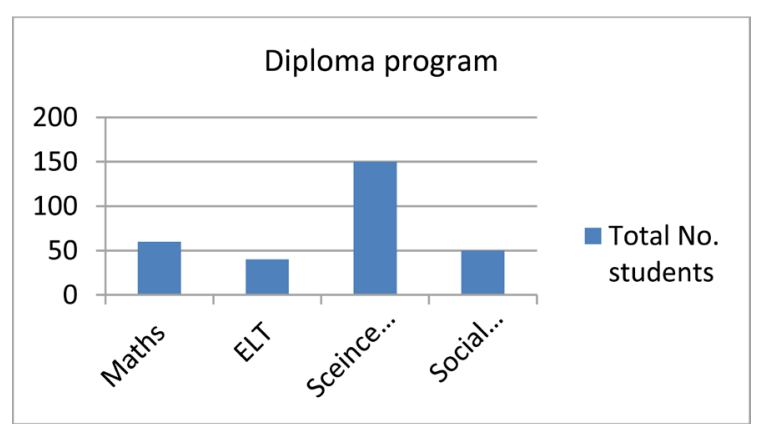

Graph 4. Participants according their department. 


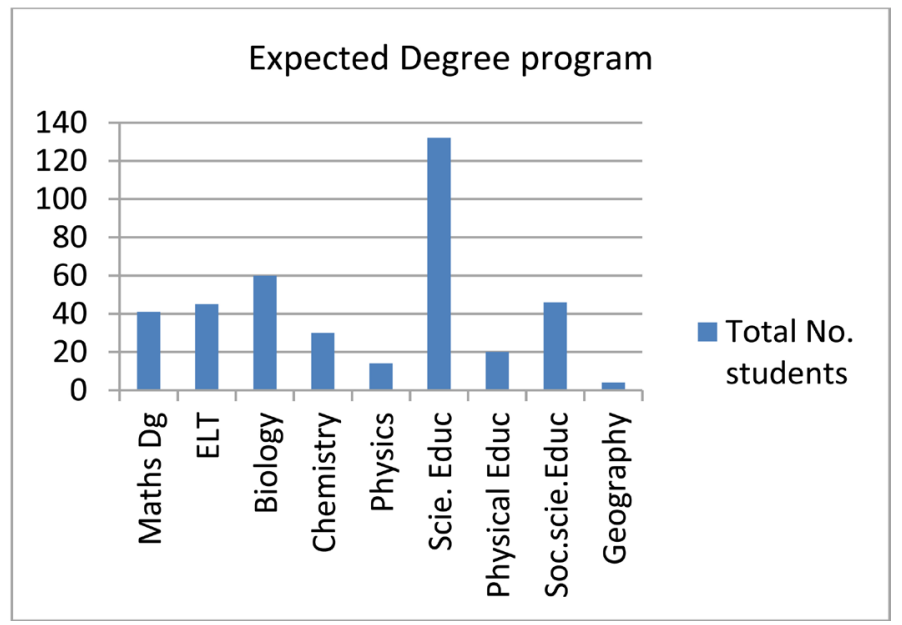

Graph 5. The expected degree program.

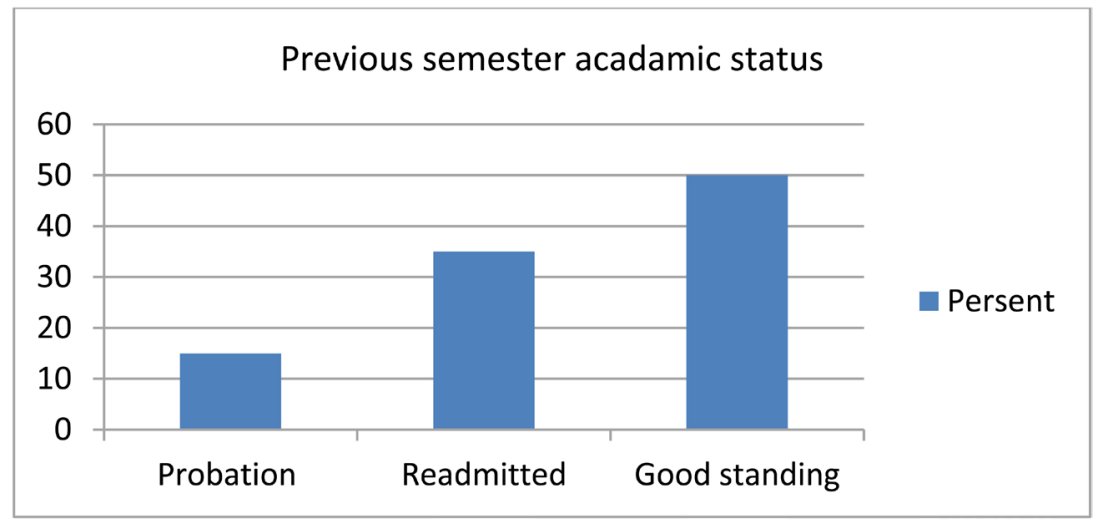

Graph 6. Previous academic status.

for the questions in the semi-structured interview form with some suggestions of pre-service teachers and academic supervisors are given below.

The view of the pre-service teachers regarding their concern about the program application

In the first question asked was "Did you think that you have difficulties in teaching your field of specialization before you start to teach in microteaching practice of an ideal classroom?" The majority of the participants (80\%) remark that there will be challenges for them. 2 (20\%) of 10 students-teachers think that they will not have any difficulties. 8 students think they will have problems. The sample statements for this question are given below (Graph 7).

The majority of the contestants (80\%) remark that there will be challenges for them. $2(20 \%)$ of 10 learners think that they will not have any difficulties. 8 students think they will have problems. The sample statements for this are as follows:

"Yes, I do. Every student is at a different level so I cannot decide with which level I have to start." (Math Educ.)

"Yes, People believe that every student knows how to study Science. Therefore, I think that students do not listen to me." (Science Educ.) 
"Yes, I thought there were many things about the Science. I do not believe that I have enough control." (Science Educ.)

"No, I thought that I had enough technical information and self-confidence in applying GMT so I should not be excited."(Social Science Educ.)

"Yes, I never think of being a teacher in my whole life, so it was difficult to accept this profession at first and to stand in front of a crowded pupil at most. (ELT)

The view of the pre-service teachers regarding the contribution of $\mathrm{Mi}$ croteaching

The second question was "Do you think to watch the presentation video of microteaching practices with your friends provides benefits to you?"

Also, there were some drills to explore the benefits $90 \%$ of the students stated that watching is beneficial for them and said that it is easier to evaluate advantages and disadvantages of microteaching practices. Only one student (10\%) thinks that observing the presentation altogether is not useful (Graph 8). The sample statements for this question are given below.

"Sure. Taking other peoples' ideas accurate provides recognizing weak side of myown." (ELT)

"Sure, I do. It is so valuable to recognize my own and others' weaknesses and fix them. This situation increases my level of success." (Science Educ.)

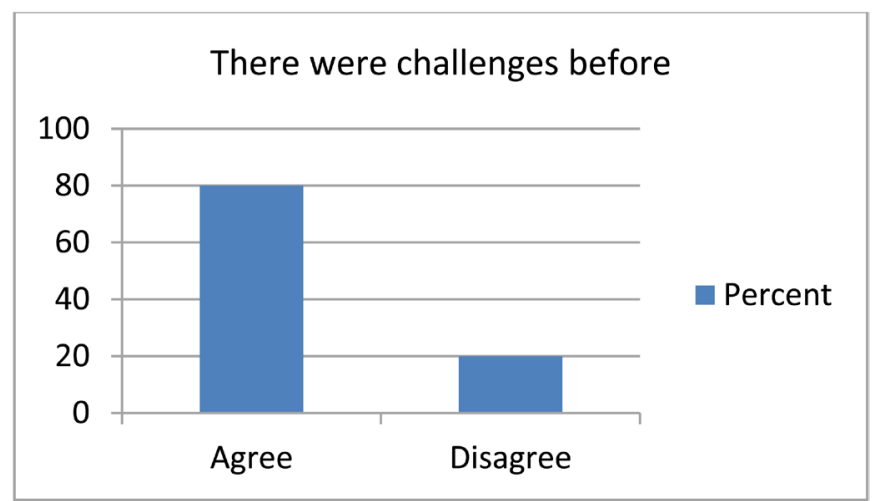

Graph 7. Challenges before the program.

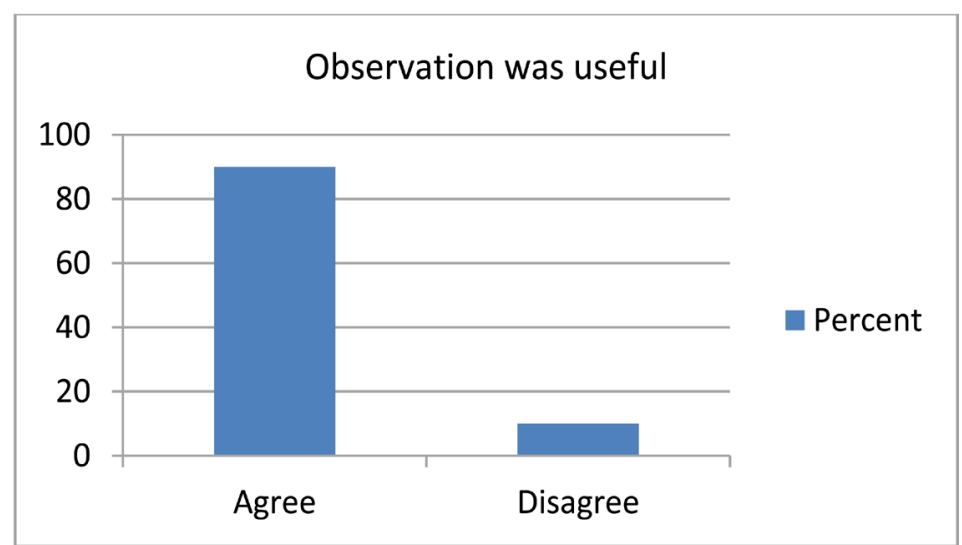

Graph 8. The contribution of watching the presentation with friends. 
"Although we have many mistakes during the lecture, we cannot understand them since the enthusiasm we have. We have an opportunity to watch ourselves in good or bad manner. After that, we will not do the same mistakes again." (Social science Educ.)

"Yes, I believe that watching videos of microteaching application contribute us in a good way. I could see my mistakes in videos very clearly." (Math Educ.)

"It must have donated, but it had not. The leading reason of this is my friend s disinclination to tell others' weak sides." (Science Educ.)

The views of the pre-service teachers regarding the difference between the first and second presentation

The next question asked was "Do you think that there is any difference between your first and second presentation?". Thus, the researchers aimed to draw results about the importance of the application.

All students in the research think that their second presentation is more successful than the first one (Graph 9). To reflect some students view stated below:-

"In the first presentation, I was inexperienced. In the second one, I was more comfortable and didn't do the same mistakes." (Science Educ.)

"Absolutely, I was inexperienced and excited in the first presentation. I felt more like a teacher in the second one." $E L T)$

"I was very excited and very nervous in the first presentation, and I could not adjust my voice. After the first presentation according to the feedbacks I lessened my excitement and control my gesture better in the second presentation." (Math Educ.)

"Sure. The practice is so different from real teaching. We have two years education at the college, but it was so exciting to feel like a teacher with real student in the real school. I think that correcting my mistakes, providing class control, having dialogues with students is better in the second presentation."(Science Educ.)

"I admit as true that the first and second presentations were so different. I saw my mistakes in the first presentation, and I try not to make them in the second presentation." (Social Science Educ.)

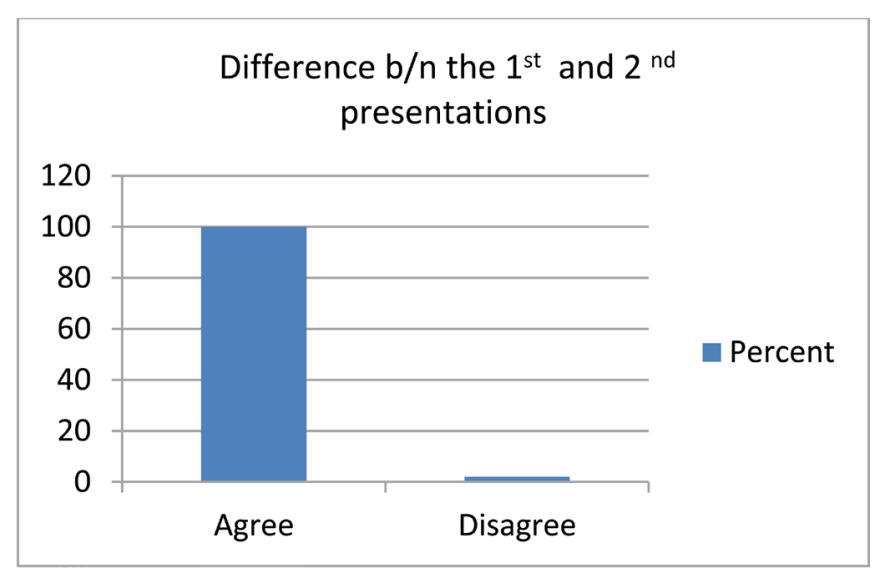

Graph 9. Difference between the first and second presentations. 
The view of the pre-service teachers concerning the contribution of the videos of other classmates

In order to find out the result of observing the each other's videos on their teaching experience, the question "Do you think that watching the presentation videos with using the microteaching technique of your friends contributes you?" was asked.

All pre-service teachers participated in research think that watching the presentation videos which use microteaching technique of other pre-service teachers was beneficial to them (Graph 10).

For example,

"I think. As a result, technology renews itself every day, and we as a teacher of technology use it in every lecture. If other friends watch videos, they can have an idea of how to use technology in the lecture and organize it." (Science Educ.)

"I think that it is helping my friends to assessment themselves objectively." (Maths Educ.)

"Of course, we discuss what mistakes did our friends and how could they correct them?' (Social Science Educ.)

"After seeing the weaknesses of my other friends also I noticed that I have the same mistakes. I think that we corrected our mistake in the unity of common view". (ELT)

The views of pre-service teachers regarding the microteaching method of teaching experience

The question "what do you think about the use of the microteaching technique in the teaching practice lesson?" was asked to evaluate the microteaching method. All pre-service teachers who participated in the research think that the microteaching method of watching themselves and their friends objectively. As part of interactive pedagogy strategy of teaching, seeing their mistakes and correcting it by themselves, should be used in future lectures (Graph 11).

"It is a request to all pre-service teachers do. It is a worthwhile practice to evaluate and correct our weakness" (ELT)

"It assisted me to see my mistakes and be careful to avoid the same mistakes. I

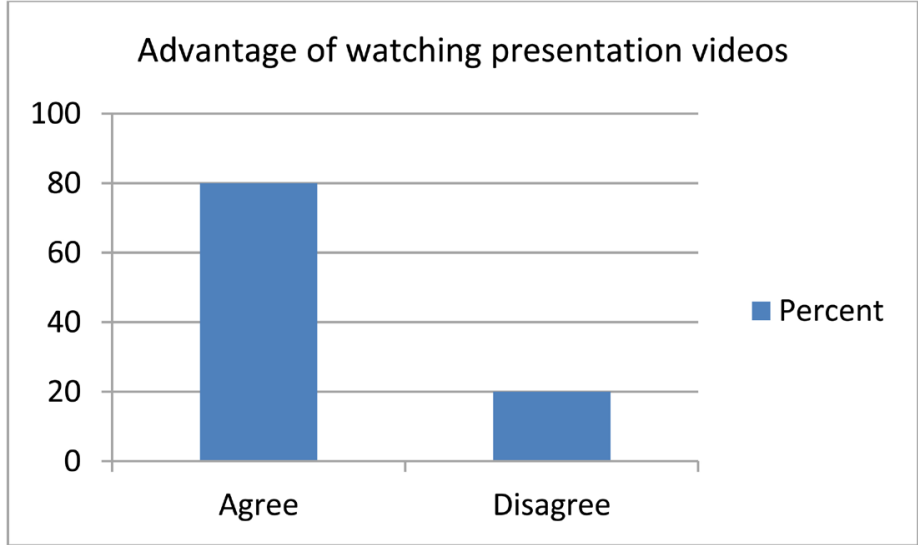

Graph 10. Contribution of videos on the program. 
think that it is useful for every pre-service teacher." (Math Educ.)

"I think that it is a beneficial repetition. We have much experience when we are watching our friends' activity in the classroom" (Science Educ.)

"The method should be applied. Watching automatically in a second eye provides a good opportunity to develop oneself. Watching other friends can prevent possible deficiencies." (Social Science Educ.)

"First of all, I did not have a positive look; after the application, I think that it is useful practice for a teacher to see themselves through the eyes of someone else" (Science Education)

The interpretations of the pre-service teaching regarding possible challenges/limitations of the microteaching presentation.

To find out the opinions of the pre-service teachers concerning the imaginable challenges confronted by a microteaching question asked "What are some restrictions on the application of microteaching methods of teaching training ?" was asked. The pre-service teachers who participated in the research said that the idea of recording in microteaching practice increased their excitement and anxiety (Graph 12).

"The statement that you are in a real classroom setting, with actual students, and the conscious knowledge that you are a teacher together with the responsibility this gives you is all very good but the fact that the lesson is recorded increases levels of excitement and anxiety. I think this is the only limitation." (Math Educ.)

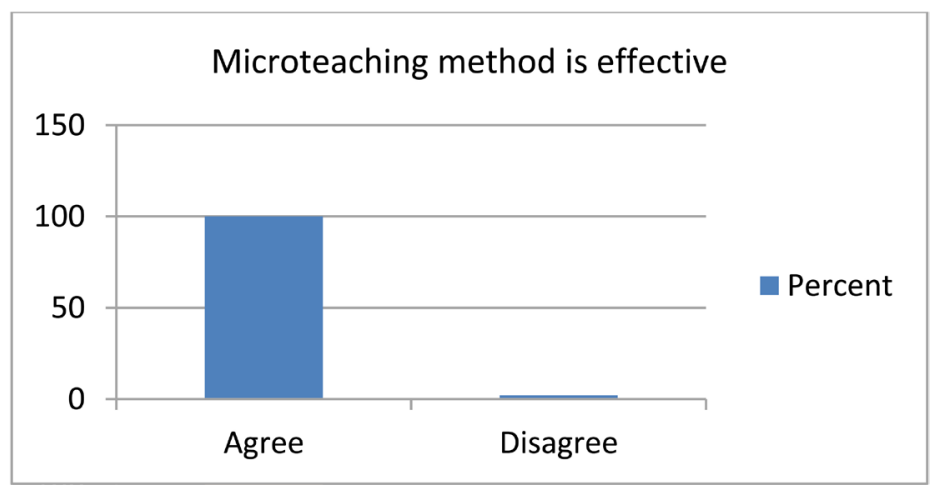

Graph 11. The effectiveness of microteaching method.

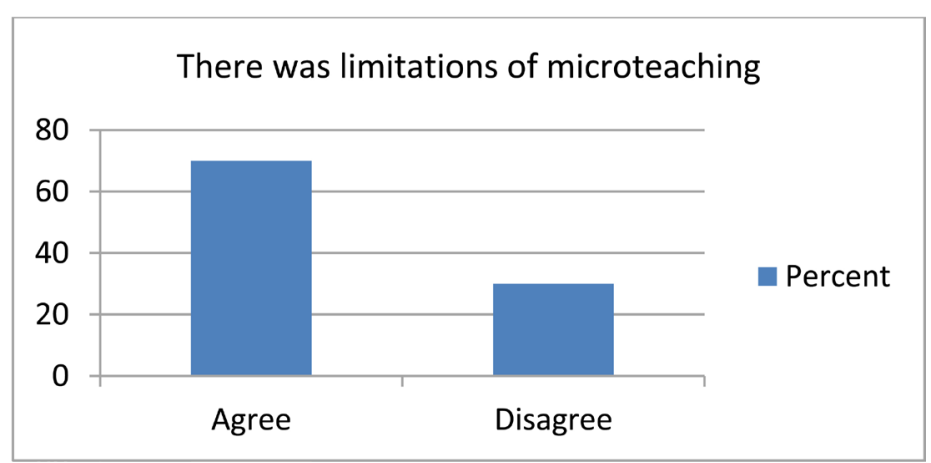

Graph 12. Limitations of microteaching. 
"Pre-service teachers cannot behave spontaneously due to the idea of recording with a camera. The recording may be reasons why students cannot behave naturally." (Social Science Educ.)

"We were excited about being recorded during the lecture and watching the recording after the lecture" (ELT)

"The camera makes us nervous, and that can be a problem from the first moment, but I do not think that it has restrictions. As a result, practice is better than theory every time." (Science Educ.)

"The microteaching method of practice was skill-oriented rather than content-oriented which forms the most important component of the teaching-learning. Therefore, it does not give adequate attention to the product of Science at all." (Social Science Educ)

"In this program timing and punctuality was among the significant challenges. Had it been the only course for me to take it would have been more effective." (Science Educ.)

\section{Recommendations}

This study's results emphasized certain vital elements of the application of microteaching experience in pre-service teacher training program. Hence, a few suggestions and implications may be discussed within the framework of the results. First, the microteaching component should continue to be integrated with courses of teaching methods of teacher education in pre-service programs in the college. The reason for its inclusion is that the microteaching experience is well-liked and highly respected by some student teachers taking the method of teaching. Second, more microteaching sessions should be more organized and aligned with different teaching strategies and skills. Third, teacher trainers and educators should pay more attention to students view and concerns regarding their performance assessment for executing mini-lessons. The student usually possesses some preconceptions about the act of teaching and the methods of evaluation because students have been sitting in classes for more than 14 years perceiving teachers using a diversity of teaching techniques to demonstrate them. Finally, more research work is required to look at subjects emphasized by the results such as the issue of assessing student teachers performance during microteaching sessions.

At present, the microteaching initiative is an optional learning component, as a part of pre-service undergraduate teacher education programmes at the college. Those who have participated in this initiative believe that the experiences have significantly enriched their understanding and vision as teachers. As an example, one student a pre-service Eritrean English language teacher changed her prior perceptions of middle school students after teaching them:

These students have better English proficiency and academic competence than what I expected. They were very attentive and focused in class. Moreover, they all volunteer to answer my questions. In the future, I need to pay attention 
to ... the great variation in my students' level. ... If necessary, I need to prepare different sets of learning tasks, just in case.

Moreover, another high school teacher Samuel (pseudonym), a pre-service Science teacher, learned to manage a class to facilitate his students' learning in science:

The teaching service in Asmara Comprehensive Secondary was an incredible experience in learning to teach. I explore how classroom management can be used as a means to facilitate teaching and learning. I no longer feel uncomfortable if my future students have different learning styles (from mine). I will try different methods in my lessons to encourage them in learning.

Even though his experience was about teaching science at Asmara, a context very different from his future professional setting, he nevertheless believes that he gains enough confidence in adapting himself to his students' learning styles so that he could encourage them in learning.

The suggestions of 10 participants were considered to contribute to a better application. The teacher applicants who took part in the research using micro-teaching methods on their teacher candidate friends should have a command over the tools and equipment as well as the materials before the class begins, they should behave in a relaxed and natural way, and they should listen to the criticism and try to amend their deficiencies.

"The pre-service teachers, who are implementing microteaching, should have technical and formation knowledge. First of all, we must be willing to do this and arrange the necessary equipment and materials before the lecture." (Science Educ.)

"Pre-service teachers cannot behave spontaneously due to the idea of recording with a camera. Moreover, some common students misbehavior should be avoided like late coming, teasing, doing other coursework in the middle of the session and others seeking attention behaviors'. They should behave normally." $(E L T)$

"Listen to the criticism of your friends, so you do not make the same mistakes and correct your weakness in other lectures." (Social Science Educ.)

"It will be helpful to students if they try to minimize the fact they are going to be recorded and behave naturally." (Maths Educ.)

"When they give the lecture, they should feel like a teacher, not a student. It will be more efficient." (Science Educ.)

"Although the teaching practice plays the most significant effort in teacher education, it should at least be given much credit. Otherwise, the work and the vale gave it is not balanced." (Science Educ.)

"When we have access to evaluate our friends, we need evaluation checklist to fill to simplify and concentrate on the necessary skills and as a means of self-assessment." (Social Science Educ.)

For suggestions of the pre-service teachers towards academic staff or supervisors of the micro-teaching practice, "what is your suggestion to the advisor of 
the academic staff about the implementation of microteaching method?" was asked. Teacher applicants who took part in the research suggest that faculty member advisers should use microteaching techniques in their real classes as a technique for: students relax and usually behave while benevolent the lesson, to deliver constructive criticism, and to enlighten teacher applicants on the subject of micro-education techniques.

"As we create it helpful to sit and watch the recording that our teacher made via the video camera with our other teacher candidate friends I can make a parallel recommendation to other member advisors" (Math Educ)

"Advisor of academic staffs should help students to relax during the presentations. They should help students normally have. Also, I think that should make positive criticism to students without hurting their self-efficacy during the evaluation of microteaching practice" (Science Educ.)

"The criticism should be optimistic. They should be cautious about this while they are watching the planning and presentations." (Science Educ.)

"I suggested that they should motivate students. Also, they should provide the necessary equipment and information to students." (Math Educ.)

"Before the implementation, advisor of academic staff should make a pre-speech about the advantages, Disadvantages, and objects of microteaching practice. They should use fruitful and polite language during the criticism." $(E L T)$

"The credit to the whole microteaching practice should be at list one-fourth of the entire teaching practice program and equal distribution among planning, teaching, and criticism." (Social Science Educ.)

\section{Results and Conclusion}

To make micro-teaching learning an essential factor of initial on Eritrean teacher education programs, teacher education institutions should take a few imperative steps. Institutions should provide staffing and financial resources to support micro-teaching learning activities with a proper institutional infrastructure. Teacher educators also need to work closely with different community partners "who have shared, mutual goals and equal roles" in the country and beyond, so that the initiative "provides equally rewarding benefits for all partners involved" [23]. Also, pedagogical frameworks for micro-teaching learning such as Shaw [24] authentic culturally engaging framework need to be developed and refined so that pre-service teachers can better prepare for the learning challenges ahead. For this reason, teacher educators who are interested in learning more about the initiative and working together on the similar initiative are most welcome.

Microteaching is essential education component that gives a chance of teaching practice to pre-service teachers [25]. Therefore, microteaching presents advantages like self-confidence, seeing and fulfilling the shortcomings, learning different methods and techniques [26]. So, the place of microteaching in education is essential. This is a result indicated by different researchers on mi- 
cro-teaching applications by pre-service teachers that will contribute positively to this lesson to go on more usefully and efficiently. To this end, this research was carried out with 10 participants and following results came out.

Pre-service students at the Department of Science Education and Social science education teacher training, as a result of microteaching activity, remark that they will have challenges in teaching. That is to say, they say that they will have some teaching anxiety following teaching experience. Regarding the microteaching applications, the majority of the students agree that video watching is useful. Similarly, all the participants state that watching videos of all classmates together contributes much. To eliminate the concerns mentioned above, these two findings are parallel with the findings of other researchers on the usefulness of watching the video (Gaudin \& Chaliès, 2015; Hatch, Shuttleworth, Jaffee, \& Marri, 2016; Osmanoglu, 2016) [27] [28] [29]. The participants state that there is the difference between their first and second presentations, which indicate that they are more experienced as thus they make fewer mistakes. Another finding is that almost all the pre-service teachers find that microteaching application is useful and essential. Watching their own videos and friends' video together helped them to see what they do right or wrong, and this will contribute much to their own future lessons. These two findings are parallel with the ones that indicate that micro-teaching promotes their experience and skills. The pre-service teachers see "recording the lesson" as one of the possible problems. They state that recording causes concern and excitement and this is a problem for them. Harlin [30] agrees that recording can be a problem for learners, but it is essential for the remark. The last parts of the questions are related to the suggestions of the students towards microteaching application and academic staff. The pre-service teachers stress the importance of equipment used in class as well as lesson ingredients before starting the lesson. Flexibility in the class is another point stated by the participants. As for the suggestions for academic staff, they should help the students to feel comfortable and relaxed during microteaching. Their criticism should be constructive and helpful. Similarly, as it is been suggested in [21] and [31], academic staff should be guided while implementing micro-teaching.

Based on these descriptions and findings, a micro-teaching method in school experience is the expansion of all the practices of departments of the college; the fact that mainly the teaching profession can be said to be beneficial. However, additional time should be provided for the preparation of pre-service teachers for pre-service teachers in acquiring knowledge and skills as faculty. It is also a useful way where candidates should focus on the profession by considering himself as a teacher and collaboratively working compatibly with their counterparts. Apparently, teaching topics and concepts in the curriculum with school administration and practice of teacher must help to pre-service teachers in any way in providing a wide range of materials and the possibility of the laboratory. The college should take the thoughtful application of pre-service teachers while 
experienced teacher should follow pre-service at the school.

At the end of the cycle, microteaching practice give pre-service teachers have the opportunity to evaluate their strength, weaknesses and try to improve weak side to change their attitude. It seems that most of the fear of teachers disappears at the end of the application, and widespread microteaching practice was seen to be equivalent to one-year trainee teacher is emphasized.

This study looked at the impact of microteaching experience on the views of prospective teachers in General Methods of Teaching (GMT) pre-service education program. It mainly focused on the salient concepts that emerged as a result of presenting mini-lessons to colleagues in simulated situations. A mixture of quantitative approach was utilized to collect relevant data from groups of GMT trainees who were taking microteaching methods. The overall effects of this study established that the inclusion of micro-teaching in teacher training programs is viewed to have a positive impact on student teachers' awareness and attitudes regarding teaching competencies. The data provide clear evidence that prospective teacher appreciated the beneficial experiences of microteaching in developing effective instructional strategies. The overwhelming benefits of microteaching justify its use and why it is well-liked by prospective teachers. A significant result highlighted pre-service teachers' concern about the issue as assessing their issue of assessing students' performance during microteaching sessions. Future studies should specifically focus on pre-service teachers' pre-conceptions and predetermined criteria for assessing microteaching experiences in teacher education program.

\section{References}

[1] Kember, D. and Leung, D.Y. (2005) The Influence of the Teaching and Learning Environment on the Development of Generic Capabilities Needed for a Knowledge-Based Society. Learning Environments Research, 8, 245. https://doi.org/10.1007/s10984-005-1566-5

[2] Gess-Newsome, J. (2015) A Model of Teacher Professional Knowledge and Skill Including PCK. Re-Examining Pedagogical Content Knowledge in Science Education. 28-42.

[3] Crosby, R.H. and Joy, C. (2000) AMEE Guide No 20: The Good Teacher Is More than a Lecturer-The Twelve Roles of the Teacher. Medical Teacher, 22, 334-347. https://doi.org/10.1080/014215900409429

[4] Avalos, B. (2011) Teacher Professional Development in Teaching and Teacher Education over Ten Years. Teaching and Teacher Education, 27, 10-20. https://doi.org/10.1016/j.tate.2010.08.007

[5] Gao, X. (2015) Promoting Experiential Learning in Pre-Service Teacher Education. Journal of Education for Teaching, 41, 435-438. https://doi.org/10.1080/02607476.2015.1080424

[6] Martin, A.D. (2016) The Professional Identities of Mainstream Teachers of English Learners: A Discourse Analysis. Montclair State University, Montclair.

[7] Saban, A. and Çoklar, A.N. (2013) Pre-Service Teachers' Opinions about the Micro-Teaching Method in Teaching Practice Classes. TOJET: The Turkish Online Journal of Educational Technology, 12, 234-240. 
[8] Campos-Sánchez, A., et al. (2013) Microteaching as a Self-Learning Tool. Students' Perceptions in the Preparation and Exposition of a Microlesson in a Tissue Engineering Course. Journal of Technology and Science Education, 3, 66-72. https://doi.org/10.3926/jotse.71

[9] Lave, J. and Wenger, E. (1991) Situated Learning: Legitimate Peripheral Participation. Cambridge University Press, Cambridge. https://doi.org/10.1017/CBO9780511815355

[10] Allen, D.W. (1967) Micro-Teaching, A Description.

[11] Otsupius, I.A. (2014) Micro-Teaching: A Technique for Effective Teaching. African Research Review, 8, 183-197. https://doi.org/10.4314/afrrev.v8i4.15

[12] Clift, J., et al. (1976) Structure of the Skill Acquisition Phase of a Microteaching Programme. British Journal of Educational Psychology, 46, 190-197. https://doi.org/10.1111/j.2044-8279.1976.tb02311.x

[13] Aydin, I.S. (2013) The Effect of Micro-Teaching Technique on Turkish Teacher Candidates' Perceptions of Efficacy in Lesson Planning, Implementation, and Evaluation. Electronic Journal of Social Sciences, 12, 67-81.

[14] Görgen, I. (2003) The Effect of Microteaching Practises on Student Teachers' Views of Giving Lessons in the Classroom. Journal of Hacettepe University Education Faculty, 24, 56-63.

[15] Ajayi-Dopemu, Y. and Talabi, J. (1986) The Effects of Videotape Recording on Microteaching Training Techniques for Education Students. Journal of Educational Television, 12, 39-44. https://doi.org/10.1080/0260741860120105

[16] Majoni, C. (2017) Assessing the Effectiveness of Microteaching during Teacher Preparation. European Journal of Research and Reflection in Educational Sciences, 5, 31-36.

[17] Kochhar, S. (1992) Methods and Techniques of Teaching. Sterling Publishers Pvt. Ltd.

[18] Allen, D.W. and Eve, A.W. (1968) Microteaching. Theory into Practice, 7, 181-185. https://doi.org/10.1080/00405846809542153

[19] Uzun, N. (2012) A Sample of Microteaching in Environmental Education and Its Effect on Pre-Service Teachers' Presenting Effective Lessons. Asia-Pacific Forum on Science Learning and Teaching, 13, Article 9.

[20] Fernandez, M.L. (2010) Investigating How and What Prospective Teachers Learn through Microteaching Lesson Study. Teaching and Teacher Education, 26, 351-362. https://doi.org/10.1016/j.tate.2009.09.012

[21] Peker, M. (2009) Pre-Service Mathematics Teacher Perspectives about the Expanded Micro-Teaching Experiences. Journal of Turkish Educational Science, 7, 353-376.

[22] Rena, P. (2005) Gender Disparity in Education-An Eritrean Perspective.

[23] Murrell Jr., P.C. (2001) The Community Teacher: A New Framework for Effective Urban Teaching. ERIC.

[24] Shaw, D. (2017) Accomplished Teaching: Using Video Recorded Micro-Teaching Discourse to Build Candidate Teaching Competencies. Journal of Interactive Learning Research, 28, 161-180.

[25] Stahl, G., Sharplin, E. and Kehrwald, B. (2018) Addressing the Needs of Pre-Service Teachers Through the "Real-Time Coaching for Pre-Service Teachers Model". In: Real-Time Coaching and Pre-Service Teacher Education, Springer, Berlin, 31-50. https://doi.org/10.1007/978-981-10-6397-8_3 
[26] Ningsih, Y. (2017) Performance of Learning Processes in a Micro Teaching Class at Ar-Raniry Islamic National University. English Education Journal, 8, 553-561.

[27] Osmanoglu, A. (2016) Prospective Teachers' Teaching Experience: Teacher Learning through the Use of Video. Educational Research, 58, 39-55. https://doi.org/10.1080/00131881.2015.1117321

[28] Gaudin, C. and Chaliès, S. (2015) Video Viewing in Teacher Education and Professional Development: A Literature Review. Educational Research Review, 16, 41-67. https://doi.org/10.1016/j.edurev.2015.06.001

[29] Hatch, T., et al. (2016) Videos, Pairs, and Peers: What Connects Theory and Practice in Teacher Education? Teaching and Teacher Education, 59, 274-284. https://doi.org/10.1016/j.tate.2016.04.011

[30] Harlin, E.-M. (2014) Watching Oneself Teach-Long-Term Effects of Teachers' Reflections on Their Video-Recorded Teaching. Technology, Pedagogy and Education, 23, 507-521. https://doi.org/10.1080/1475939X.2013.822413

[31] Galloway, G., Roy, I. and Adu, E.O. (2017) The Relationship between Pre-Service Trainee Teachers and Learners in the Foundation Phase. International Journal of Educational Sciences, 16, 114-120. https://doi.org/10.1080/09751122.2017.1311639 